\title{
Transhepatic endoscopic gastrostomy
}

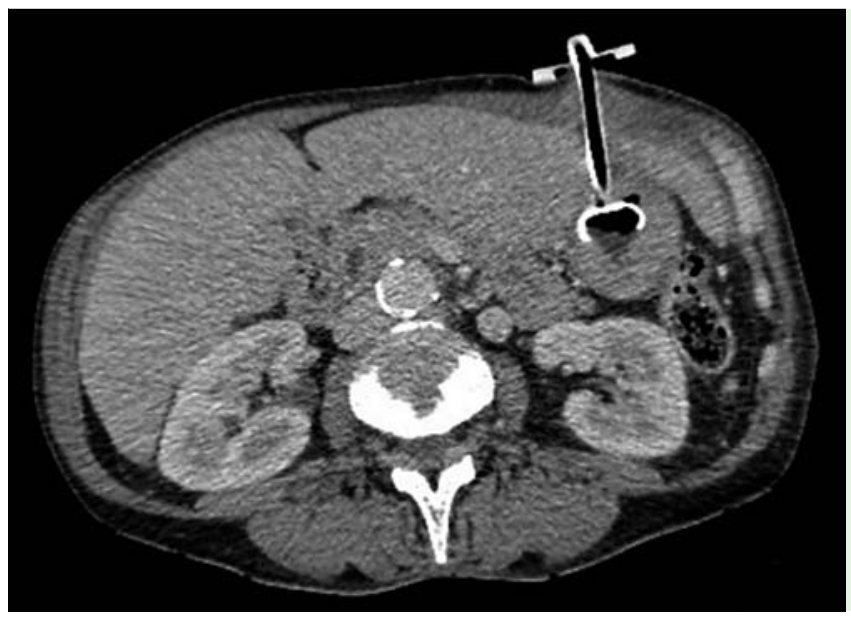

Fig. 1 Computed tomography (CT) scan showing marked hepatomegaly with the percutaneous endoscopic gastrostomy (PEG) tube incorrectly placed within the liver.

A 55-year-old woman was referred for insertion of a percutaneous endoscopic gastrostomy (PEG) feeding tube prior to surgical treatment of a squamous cell carcinoma of the tongue. Clinical signs and biological data did not indicate liver disease, except for chronic alcohol consumption. A 20-Fr gastrostomy tube (MIC PEG tube; Kimberly-Clark Health Care) was placed endoscopically using the pull technique [1] after transillumination and finger pressure, without any immediate complications.

Tube feeding was well tolerated until 1 week later, when the patient complained of local pain around the gastrostomy, but with no local or biological inflammatory signs. A computed tomography (CT) scan revealed marked hepatomegaly with the tube in an intrahepatic position, but no evidence of abscess or hematoma formation ( Fig. 1). There are only two reports of intrahepatic gastrostomy in the literature: one where acute hemorrhage occurred during tube placement (managed surgically) [2], and one which was well tolerated until tube replacement [3].

As a precaution we removed the PEG tube. No hemorrhage occurred. Three months later, there had been no complications relating to the incorrect placement of the tube. The patient was being fed by a surgical gastrostomy.

To avoid such adverse events, we could have used the safe-tract technique [4], in which suction is applied with a syringe as the angiocath is advanced, an interposed lumen being detected if air or fluid is drawn into the syringe. However, this test might have been uninformative in this case because passage through the liver parenchyma may not cause a return of blood into the syringe. In patients such as this woman with squamous cell carcinoma of the head and neck, alternative push techniques such as Russell's transabdominal introduction of a gastrostomy tube under endoscopic visualization [5] or a percutaneous radiological gastrostomy (under fluoroscopic guidance) [6] would have been preferable as they avoid the risk of developing metastatic tumor deposits at the gastrostomy site, which carry a grave prognosis [7].

Endoscopy_UCTN_Code_CPL_1AH_2AI

Competing interests: None
Pascale Mercky, Aude Le Goffic, Philippe Ah-Soune

Gastroenterology Department, Sainte Musse Hospital, Toulon, France

\section{References}

1 Gauderer MWL, Ponsky JL, Izant RJ. Gastrostomy without laparotomy: a percutaneous endoscopic technique. J Pediatr Surg 1980; 6: 872

2 Wiggins TF, Kaplan R, DeLegge MH. Acute hemorrhage following transhepatic PEG tube placement. Dig Dis Sci 2007; 52: 167 169

3 Chaer RA, Rekkas D, Trevino J et al. Intrahepatic placement of a PEG tube. Gastrointest Endosc 2003; 57: 763-765

4 Foutch PG, Talbert GA, Waring JP et al. Percutaneous endoscopic gastrostomy in patients with prior abdominal surgery: virtues of the safe tract. Am J Gastroenterol 1988; 83: $147-150$

5 Russell TR, Brotman M, Norris F. Percutaneous gastrostomy: a new simplified and cost-effective technique. Am J Surg 1984; 148: $132-137$

6 Preshaw RM. A percutaneous method for inserting a feeding gastrostomy tube. Surg Gynecol Obstet 1981; 152: 658-660

7 Huang AT, Georgolios A, Espino S et al. Percutaneous endoscopic gastrostomy site metastasis from head and neck squamous cell carcinoma: case series and literature review. J Otolaryngol Head Neck Surg 2013; 42: 20

Bibliography

DOI http://dx.doi.org/

10.1055/s-0034-1377367

Endoscopy 2014; 46: E385

(C) Georg Thieme Verlag KG

Stuttgart · New York

ISSN 0013-726X

Corresponding author

Pascale Mercky, MD

Gastroenterology Department

Hôpital Sainte Musse

54 rue Sainte Claire Deville

83100 Toulon

France

Fax: +33-494-145276

pascale_mercky@hotmail.com 